\title{
Use of an algorithm in choosing abdominoplasty techniques
}

\section{Emprego de um algoritmo na escolha de técnicas de abdominoplastia}

\author{
Júlio Wilson Fernandes, tCbC-PR; Renata Damin²; Marcos Vinicius Nasser Holzmann³; Gabriel Gomes de Oliveira Ribas ${ }^{3}$
}

\begin{abstract}
A B S T R A C T
Objective: to validate an algorithm for the choice of the abdominoplasty surgical technique among the five approaches established in the literature, according to the characteristics of the abdominal wall. Methods: we conducted a retrospective study of 245 patients undergoing abdominoplasty, for whom the method of choice of the surgical technique was the proposed algorithm, based on the degree of abdominal flaccidity determined by bimanual maneuver. We studied its applications and conveniences, as well as the complications inherent in each group studied. Results: according to the algorithm used, the most frequently chosen technique was "Technique IV" (transverse dermolipectomy of Pitanguy - or with a Baroudi-Kepke incision), in 25.71\% of the cases. "Technique I" (mini abdominoplasty) had the lowest incidence and the lowest rate of complications. On the opposite, "Technique III", dermolipectomy with remaining vertical scarring, presented a higher incidence of complications, requiring extreme caution in its indication, particularly in relation to patients' expectations regarding the resulting scar and its legal aspects. Among all conducts, the most frequent complication was seroma, with a $10.2 \%$ occurrence, solved by simple syringe aspiration and use of elastic compression mesh. Conclusion: the proposed algorithm facilitated the choice of abdominoplasty techniques, offering satisfactory results, which are in line with the complication rates published in the world literature.
\end{abstract}

Keywords: Abdominoplasty. Lipectomy. Abdominal Wall. Surgery, Plastic.

\section{INTRODUCTION}

$\mathrm{T}$ he abdominal wall presents an important aesthetic and functional aspect in the human anatomy, being particularly affected by gestations, obesity, hernias and eventrations. The abdominal muscles and the sheath of the rectus abdominis muscle are of great importance in visceral restraint, in the dynamics to efforts and in postural aspects, also influenced by aging, reduced local innervation and bariatric procedures ${ }^{1}$. In the social, sporting and sensual ambit, the abdomen plays a relevant role, and its alterations can contribute to low self-esteem, with inconvenient psychological and family consequences. Currently, there has been an increase in the demand for abdominoplasty for patients who have undergone bariatric surgery, which corroborates the increase in the number of men in a sample previously dominated by women ${ }^{1,2}$.
The techniques of abdominal dermolipectomy preceded its application in Plastic Surgery, being previously used in General Surgery, particularly in the treatment of great hernias. Dermolipectomies were performed mainly in obese patients, in order to facilitate the approach to umbilical hernias. With the development and diffusion of the technique, many authors have developed specific instruments to aid in abdominal dermolipectomies, such as the La Roe retractors, the Skoog forceps (1955), the Pitanguy marker clamp and many others ${ }^{3,4}$.

In the beginning, the abdominoplasty was limited to the direct resection of the skin and fat excess and correction of the underlying hernias, eventrations and diastases. With the advent of liposuction and its application in abdominoplasty, around 1980, professionals were able to achieve better aesthetic results for the procedure ${ }^{5}$. Initially, many authors reported an increase in the incidence of seroma, when liposuction was applied

1 - Positivo University, Discipline of Surgery (Plastic Surgery), Curitiba, PR, Brazil. 2 - Evangelical University Hospital of Curitiba, General Surgery Service, Curitiba, PR, Brazil. 3 - Evangelical University Hospital of Curitiba, Medical School, Curitiba, PR, Brazil. 
in previously detached regions ${ }^{3,6}$. Subsequent studies have shown that liposuction does not increase morbidity or particularly the incidence of seroma when used as an adjuvant in abdominal dermolipectomies 7,8 . Currently, liposuction is consecrated as a possible alternative to abdominal dermolipectomy, as a method associated with traditional techniques, or in the lipoabdominoplasty described by Juarez Avelar and refined by Osvaldo Saldanha, with innovative results ${ }^{9}$.

Regarding the umbilical scar, the vast majority of the described techniques displays satisfactory results when there is sufficient flaccidity of the detached skin, to the point of allowing skin resection to the periumbilical circular incision performed to keep the umbilicus fixed in the abdominal wall. This is a point of great importance in trying to avoid a vertical scar in the midline of the lower abdomen ${ }^{1,10}$. However, when the flaccidity is not ideal, choosing the best surgical technique for abdominoplasty can be a difficult decision. In addition, it is of great importance, for ethical and legal reasons, that the patient be aware of and accept the unpredictability in the appearance of the remaining scars after abdominal dermolipectomy, especially those that cannot be concealed by the usual bathing suits.

The present study aims to validate an algorithm (Figure 1) to facilitate the indication of abdominoplasty techniques, among five approaches already established in the literature, using it in 245 patients. We studied its applications and conveniences, as well as the inherent complications of each group studied, in order to help in choosing the best technique.

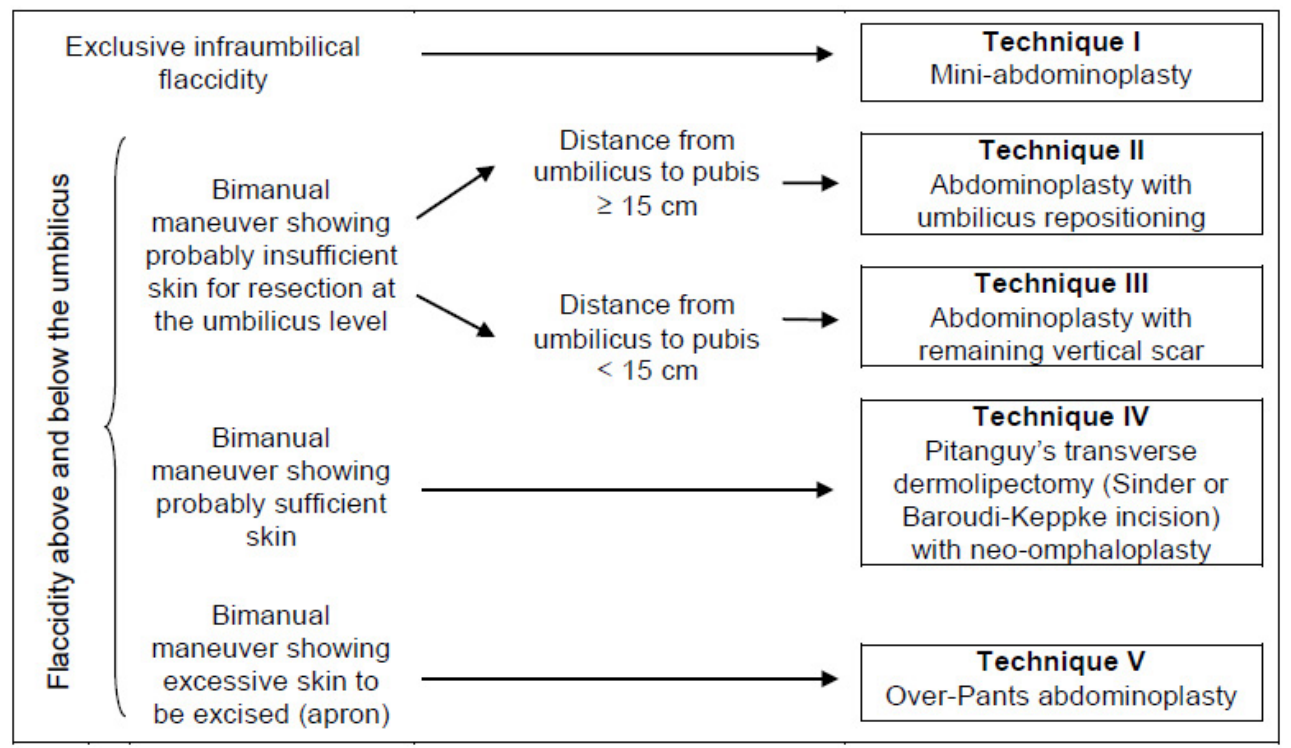

Figure 1. Proposed Algorithm.

\section{METHODS}

For the retrospective study, were selected 245 patients operated over a period of 24 years (1991-2015), during which we used the described algorithm. We did not include patients submitted to associated procedures, patients after bariatric surgery, and those who needed other techniques not contemplated in the algorithm (Figure 1), which combined five traditional techniques for abdominoplasty with the findings of physical examination of each patient. This algorithm was developed for the selection of the procedure among the following five surgical techniques:

Technique I-Detachment and dermolipectomy of the lower abdomen with liposuction: also known as "Miniabdominoplasty" or "Mini Tummy Tuck", this procedure is limited to supra pubic dermal resection, with eventual plication of the infraumbilical fascia in the midline, associated with local lipectomy using the liposuction ${ }^{10}$. In these cases, it is also possible to reduce 
waist circumference and to smooth the iliac fossa by plication of the oblique muscles ${ }^{10}$. The umbilical scar remains intact in this type of approach ${ }^{10-12}$.

Technique II - Detachment of the umbilicus at its base and reinsertion a few centimeters below: a variation of the Pitanguy Transverse Dermolipectomy with transoperative liposuction of the anterior, lateral and lumbar region, described as a "Group IV" technique by Bozola10,11. The umbilical scar is detached from the linea alba in a "glove finger" fashion, without any incision in the skin, for later reinsertion a few centimeters below.

Technique III - Abdominoplasty with remaining vertical scar: in the absence of enough skin to caudally traction the flap and allow excision of the previous site of the umbilical scar, there is a need for vertical incision in the midline as a remnant scar, which in some cases may be taken to the horizontal scar by setting an inverted " $\mathrm{T}$ ". In post-bariatric patients, a long vertical incision may be necessary to achieve better results and allow more easily corrected hernias ${ }^{13}$.

Technique IV - Pitanguy Dermolipectomy: Classic transverse dermolipectomy, described by Pitanguy, with its incision performed along the upper limit of the pubic line. The incision has undergone variations in its design such as those of Sinder and Baroudi-Keppke, who position the scar laterally, parallel to the inguinal region ${ }^{14}$. When the detached flap reaches the umbilical height in the supra-aponeurotic plane, it is divided caudally along the midline of the abdomen and the circumferential incision is made around the umbilicus. The dissection continues until the costal margin is reached, leaving the umbilical scar attached by its pedicle to the anterior abdominal wall. The two sides of the flap are then tractioned inferiorly and medially, in order to estimate the amount of tissue to be excised ${ }^{14}$. Bonfatti ${ }^{1}$ uses the same approach, but with inferior traction of the flap in the lateral direction, avoiding the need for future surgical corrections on the sides of the abdomen. The end result, in this case, will be a slightly longer transverse scar. After resection of the exceeding adipose skin and panniculus, the umbilicus is drawn through a hole in the skin of the detached flap and is sutured to it. Aspiration drains are installed to prevent bruising at the end of surgery.

Technique V - Previous resection of the infraumbilical segment based on the Over Pants technique, by Jaime Planas ${ }^{15,16}$ : the original technique consists in the design of a triangular area, its upper angle being the umbilicus, and the base, the transverse suprapubic line. After detachment of the upper flap, it is caudally tractioned over the still undetached lower one (vest over pants maneuver), defining the extent of flap detachment, the extent of excision and the height of the resulting scar. Similarly, the technique $\mathrm{V}$ in our selection promotes a direct previous resection, without the need of over pants, optimizing time and hemostasis, without the need of the uncomfortable support of a heavy flap by the surgical assistant during abdominoplasty.

For the technique choice, through the use of the algorithm, we previously considered two parameters: 1) The distance from the pubis to the umbilicus, usually 14 to $15 \mathrm{~cm}$, at the L3-L4 level17,18; 2) The flaccidity of the skin, as evidenced by the bimanual maneuver: the patient is positioned in dorsal decubitus, with flexed elbows, thus presenting a small anterior flexion of the trunk (Figure 2). The examiner clutches the flaccid abdominal tissue with both hands, checking whether the umbilicus level reaches the pubic region: the tissue to be excised is contained between the thumb and the other four fingers of the examiner's hands (Figure 2). Considering these parameters, the patients are classified into five different groups; figure 3 shows the groups submitted to the most invasive techniques (II, III, IV, V), according to their pre and postoperative characteristics.

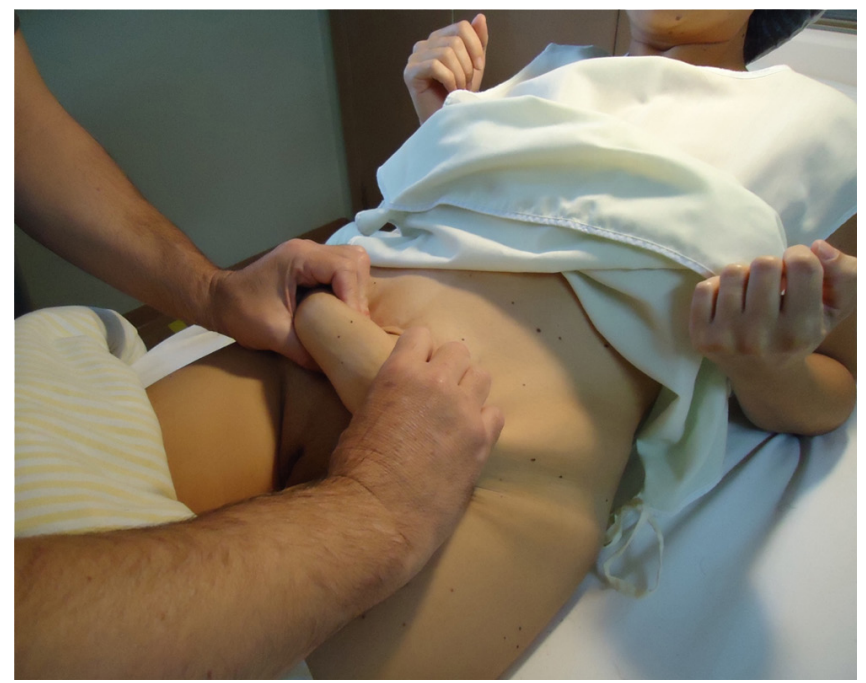

Figure 2. Bimanual Maneuver. 


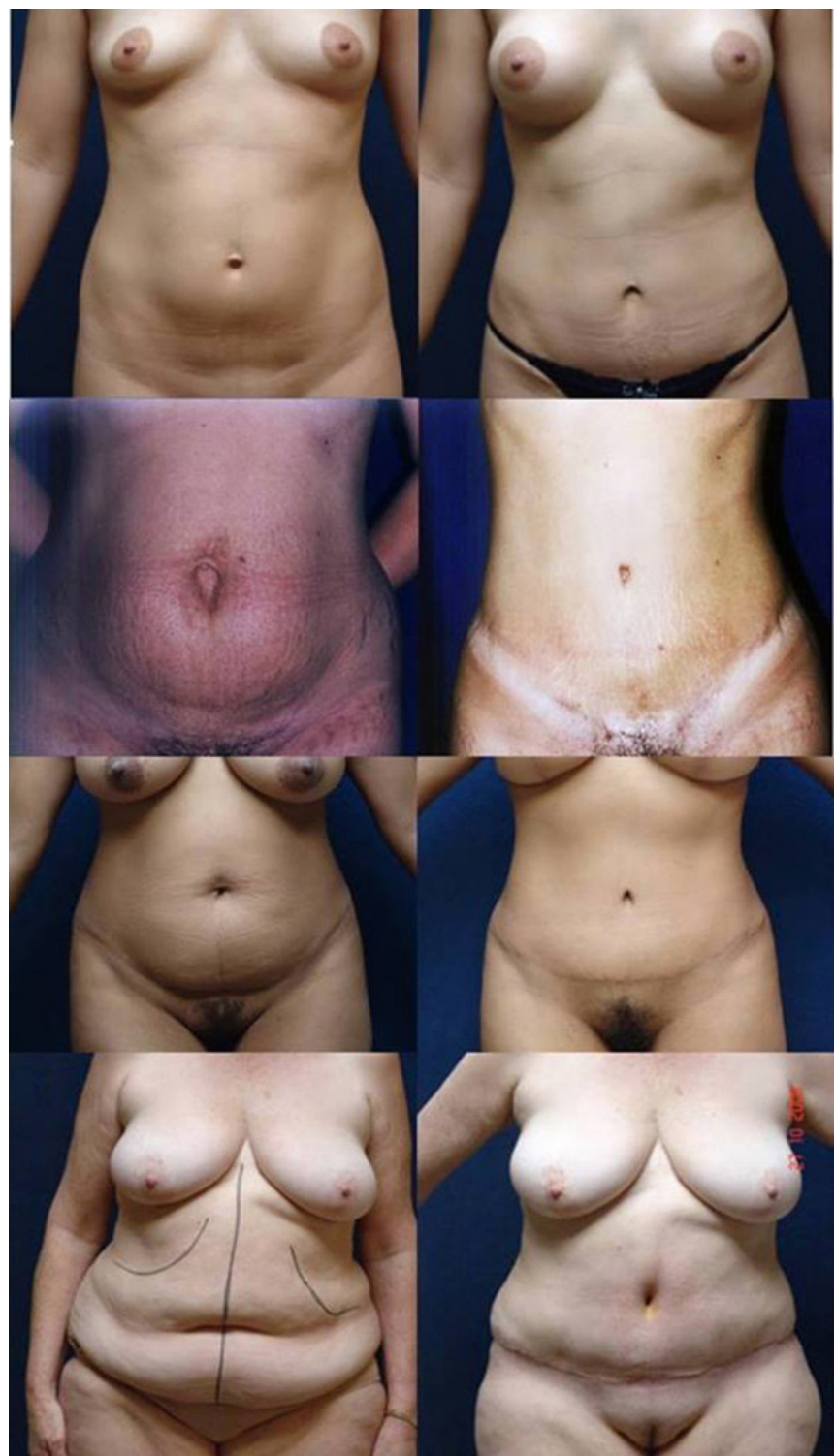

Figure 3. Pre and postoperative techniques /I to $\mathrm{V}$.

Then, the algorithm proposed assigned a technique for each of the groups, based on the characteristics found in each patient (Figure 1). The Technique I group comprised patients with flaccidity and/or lipodystrophy just below the umbilicus: the miniabdominoplasty technique was indicated for this situation, considering that there was no reason to detach the flap in the upper portion of the abdomen, or repositioning of the umbilicus. When there was flaccidity in the upper and lower abdomen, but the bimanual test showed not enough flaccid skin for scar resection due to umbilical circumcision, two situations were considered: the first was when the distance from the umbilicus to the pubis was greater than or equal to $15 \mathrm{~cm}$, an indication for Technique II, when abdominoplasty was performed with repositioning of the umbilicus; the second situation was when the distance from the umbilicus to the pubis was less than $15 \mathrm{~cm}$, an indication for Technique III. In this case there was not enough flaccidity to resect the umbilical scar, and the supraumbilical flaccidity necessarily required traction of the skin at that level. It therefore resulted in a vertical scar in the midline, or even an inverted, lower T-scar in the lower abdomen if the flaccidity allowed it. When the bimanual test indicated the presence of sufficient skin for the resection of the original umbilicus site, we indicated the classic Technique IV: Pitanguy's transverse dermolipectomy, with Sinder or Baroudi-Kepke incision, resulting in a single transverse scar. Finally, when the bimanual test indicated a great flaccidity of the skin, also known as "apron abdomen", the patient was submitted to Technique $\mathrm{V}$, in which the previous skin resection facilitated the surgical act.

The variables analyzed were the occurrence and type of complications and their prevalence for each technique employed.

The work was submitted to, and approved by, the Institution's Ethics Committee, under the number 76367517500000103 .

\section{RESULTS}

Of the 245 patients who had the abdominoplasty technique selected with the aid of the algorithm, three were male and 242 female. The mean age was 43 years. Table 1 shows the distribution of the operated patients according to the technique selected by the abdomen characteristics.

Table 1. Prevalence of techniques employed in the 245 patients.

\begin{tabular}{lcc}
\hline \multicolumn{1}{c}{ Procedure } & $\mathrm{N}$ & $\%$ \\
\hline Technique I & 30 & 12.24 \\
Technique II & 42 & 17.16 \\
Technique III & 56 & 22.85 \\
Technique IV & 63 & 25.71 \\
Technique V & 54 & 22.04 \\
Total & 245 & 100 \\
\hline
\end{tabular}


The complications occurring in each group were seroma, hypertrophic scar, non-aesthetic scar and keloid. Table 2 presents the complications of patients operated on in our series. In more than half of patients who presented some type of complication, this was the seroma (10.2\%). The second most prevalent complication was the occurrence of a hypertrophic scar, with a $4.48 \%$ incidence. This condition, commonly confused with keloid by patients, contrasts with true keloids found in only two patients $(0.8 \%)$. Wide and hyperpigmented scars were grouped and considered as "non-aesthetic scars", and occurred in $2.04 \%$ of patients.

Table 2. Complications in the 245 patients undergoing abdominoplasty.

\begin{tabular}{lcc}
\hline \multicolumn{1}{c}{ Complication } & N & $\%$ \\
\hline Seroma & 25 & 10.2 \\
Hypertrophic Scar & 11 & 4.48 \\
Non-Esthetic Scar & 5 & 2.04 \\
Keloid & 2 & 0.81 \\
Total & 43 & 17.55 \\
\hline
\end{tabular}

Table 3 compares the total number of procedures performed of each technique and their respective complications incidence. Technique III presented the greater number of complications (21.4\%), followed by techniques IV and V, with $20.6 \%$ and $20.3 \%$, respectively. On the other hand, techniques I and II had the lowest rate of complications, with $6.6 \%$ and $11.9 \%$, respectively.

Table 3. Complications according to the abdominoplasty technique adopted.

\begin{tabular}{lcc}
\hline \multicolumn{1}{c}{ Procedure } & $\mathrm{N}$ & $\%$ \\
\hline Technique I & 30 & 6.66 \\
Technique II & 42 & 11.9 \\
Technique III & 56 & 21.42 \\
Technique IV & 63 & 20.63 \\
Technique V & 54 & 20.37 \\
\hline
\end{tabular}

\section{DISCUSSION}

The majority of patients underwent abdominoplasty through technique IV. These patients had the ideal characteristics to the classic Pitanguy technique, with upper and lower abdomen lipodystrophy, moderate to severe skin excess in the lower abdomen, and frequent striae, as well as different degrees of weakness of the abdominal wall ${ }^{19}$.

On the other hand, the group of patients with alterations restricted to the lower abdomen and submitted to miniabdominoplasty were the least prevalent, considering its strict indications. In a prospective study of 151 female patients, Sozer et al. ${ }^{19}$ demonstrated an incidence of $5 \%$ of this type of abdomen. As expected, the rate of complications was lower in patients operated on by techniques I and II, less aggressive surgical approaches.

Patients who underwent major surgeries, such as Techniques III, IV and V, had an average rate of small complications of $20.8 \%$. This shows that even when the one adopts a highly strict algorithm in order to optimize the choices, one should be prepared to face a higher rate of complications in patients who undergo major procedures, such as the Pitanguy's abdominoplasty or the Over-Pants technique, besides the greater obesity of these patients, with all their intrinsic characteristics and the greater caliber of vessels found in the transoperative period.

Staalesen et al. ${ }^{20}$ conducted a systematic review of abdominoplasty results and found that the most frequent complications, dehiscence, seroma and cellulitis, were all characterized by prolonged healing time of the postoperative wound, but with low impact on the final surgical result. The incidence of seroma has been reported between $1 \%$ and $57 \%$, with an incidence around $10 \%$, as found in our series, generally considered acceptable ${ }^{21}$. The causes of seroma can probably be attributed to rupture of the vascular and lymphatic network, stress or friction between the flap and the abdominal wall, dead space, and even release of inflammatory mediators, or simply to the empirical excessive use of electrocautery. Ardehali and Fiorentino ${ }^{21}$, in their meta-analysis, clearly 
emphasize the beneficial effect of progressive tension sutures under the flap, known as Baroudi sutures, in the prevention of seromas, as well as, less effectively, the preservation of the fascia of Scarpa on the abdominal flap.

Although subjective, the experience of the author is that, in addition to the aforementioned factors, the use of a weight of $3 \mathrm{~kg}$ to $5 \mathrm{~kg}$ between the umbilicus and the pubis, and a rigorous rest for three weeks, during which the patient is allowed to ambulate for a maximum of 20 minutes every two hours, has contributed to a significant reduction in the incidence of seromas since 2016, and drains are routinely removed in the morning after surgery, when the patient is discharged. This attitude emphasizes that the aim of the postoperative drains is to avoid hematoma, and not to prevent seroma, whose incidence is late.

Abhyankar ${ }^{22}$ and Bozola ${ }^{18}$ recommend locating the umbilicus position through distance ratios and different reference points, defining the distance ratio between the xiphoid appendix and the pubis at approximately 1.6:1 for a new aesthetically ideal umbilicus position. Although there are several descriptions for adequate umbilical positioning during abdominoplasty, only the patients of the Technique II group underwent reinsertion of the umbilicus. For cosmetic reasons, we simply avoid any reinsertion within 12 centimeters of the pubic hair line.

There were no complaints about the final scar in the charts analyzed, the follow-up being routinely one year. This fact reflects the author's policy of ostensibly informing patients about the scar as an expected consequence and demonstrating realistic pictures of scarring results considered "good" and "bad" during the consultations. The idea has been to identify, and refuse prior to the procedure, any patient who is not able to accept the wide range of possible variations in the resulting scar. However, the indication of technique III should be viewed with great caution: it is an extreme situation in which a miniabdominoplasty would not solve the flaccidity of the supraumbilical skin, and an umbilical inferior positioning would not allow sufficient skin excision without producing an unacceptably low umbilicus. In such cases, one must value the patients' complaints and their ability to understand that to eliminate or ameliorate the upper abdominal flaccidity, there will be risk of a vertical scar of unpredictable appearance in a visible place (if an inverted " $T$ " is not possible). This risk is to be accepted and formally agreed upon in the informed consent, which should be signed days before the surgical act. For some patients who do not accept the abdominoplasty scars, when a slight flaccidity of the abdominal skin is evident, a palliative liposuction may also be indicated. These patients, however, should accept a relatively unpredictable outcome regarding the resulting flaccidity, despite the improvement in the abdomen lipodystrophic appearance. When planning abdominoplasty, every surgeon should also consider the need for plication of the rectus abdominis muscle sheet, indicated in any technique by preoperative palpation, ultrasound, and especially by the transoperative aspect of the abdomen's midline.

We conclude that the proposed algorithm effectively contributed to the choice of the abdominoplasty technique of our patients. The optimization of this choice, already in the first visit, has allowed consistent information to the patients about the resulting scars, facilitating the decision towards surgery. In addition to satisfaction with the results, the levels of complications in the techniques chosen with the use of the proposed algorithm are similar to those described in the literature. 


\title{
R E S U M O
}

\begin{abstract}
Objetivo: validar um algoritmo para a escolha da técnica cirúrgica de abdominoplastia, entre as cinco abordagens consagradas na literatura, de acordo com as características da parede abdominal. Método: estudo retrospectivo de 245 pacientes submetidos à abdominoplastias, em que o método de escolha da técnica cirúrgica teve como ferramenta o algoritmo proposto, baseado no grau de flacidez abdominal determinado por manobra bimanual. Foram estudadas suas aplicações e conveniências, bem como identificadas as complicações inerentes a cada grupo estudado. Resultados: de acordo com o algoritmo empregado, a técnica mais frequentemente eleita foi a "Técnica IV" (dermolipectomia transversa à Pitanguy - ou com incisão de Baroudi-Kepke), em 25,71\% dos casos. A "Técnica I" (miniabdominoplastia) demonstrou a menor incidência e a menor taxa de complicações. A "Técnica III", dermolipectomia com cicatriz vertical remanescente, ao contrário, apresentou maior incidência de complicações, requerendo extrema cautela na sua indicação, particularmente frente às expectativas dos pacientes quanto à cicatriz resultante e seus aspectos legais. Entre todas as condutas, a complicação mais frequente foi o seroma, com 10,2\% de ocorrência entre os 245 casos operados, resolvido pela simples aspiração com seringa, e uso de malha compressiva elástica. Conclusão: o algoritmo proposto contribuiu para facilitar a escolha das técnicas na abdominoplastia, oferecendo resultados satisfatórios, que se alinham com as taxas de complicações publicadas na literatura mundial.
\end{abstract}

Descritores: Abdominoplastia. Lipectomia. Parede Abdominal. Cirurgia Plástica.

\section{REFERENCES}

1. Fernandes JW, editor. Cirurgia plástica bases e refinamentos. 2a ed. Curitiba: Primax Edições; 2012.

2. Fraccalvieri M, Datta G, Bogetti P, Verna G, Pedrale $R$, Bocchiotti $M A$, et al. Abdominoplasty after weight loss in morbidly obese patients: a 4-year clinical experience. Obes Surg. 2007;17(10):1319-24.

3. O'Toole JP, Song A, Rubin JP. The history of body contouring surgery. Semin Plast Surg. 2006;20(1):5-8.

4. Sinder R. Cirurgia plástica do abdome. Rio de Janeiro: [s.n.]; 1979.

5. Matarasso A. Classification and patient selection in abdominoplasty. Plast Reconst Surg. 1996;3(1):7-14.

6. Di Giuseppe A, Shiffman MA, editors. Aesthetic plastic surgery of the abdomen. [ebook] Springer International Publishing; 2015. Available at: http:// link.springer.com/10.1007/978-3-319-20004-0.

7. Stevens WG, Cohen R, Vath SD, Stoker DA, Hirsch EM. Does lipoplasty really add morbidity to abdominoplasty? Revisiting the controversy with a series of 406 cases. Aesthet Surg J. 2005;25(4):353-8.

8. Dillerud E. Abdominoplasty combined with suction lipoplasty: a study of complications, revisions, and risk factors in 487 cases. Ann Plast Surg. 1990;25(5):333-8.

9. Saldanha OR, De Souza Pinto EB, Mattos WN Jr, Pazetti CE, Lopes Bello EM, Rojas Y, et al. Lipoabdominoplasty with selective and safe undermining. Aesth Plast Surg. 2003;27(4):322-7.
10. Bozola AR, Psillakis JM. Abdominoplasty: a new concept and classification for treatment. Plast Reconstr Surg. 1988;82(6):983-93.

11. Bozola AR. Abdominoplasty: same classification and a new treatment concept 20 years later. Aesthetic Plast Surg. 2010;34(2):181-92.

12. Greminger RF. The mini-abdominoplasty. Plast Reconstr Surg. 1987;79(3):356-65.

13. Souto C, Tardelli HC. Cicatrização patológica: diagnóstico e tratamento. In: Mélega JM, Viterbo F, Mendes FH, editores. Cirurgia plástica - Os princípios e a atualidade. Rio de Janeiro: Guanabara Koogan; 2011. p. 9-15.

14. Converse J. Reconstructive plastic surgery; principles and procedures in correction, reconstruction and transplantation. In: Converse J, McCarthy J, Littler JW, editors. 2nd ed. Philadelphia, PA: W.B. Saunders Company; 1977. p. 3519-970.

15. Planas J. The "vest over pants" abdominoplasty. Plast Reconstr Surg. 1978;61(5):694-700.

16. Planas J, Bisbal J, del Calcho C, Palacin JM. Further advantages of the "vest over pants" abdominoplasty. Aesthetic Plast Surg. 1988;12(3):123-7.

17. Grey H. Gray Anatomia. 29th ed. Goss CM, editor. Rio de Janeiro: Guanabara Koogan; 1988.

18. Bozola AR. Abdominoplastias. In: Mélega JM, Zanini AS, Psillakis JM. Cirurgia Plástica Estética e Reparadora. Rio de Janeiro: Medsi; 1988. p. 807.

19. Sozer SO, Agullo FJ, Santillan AA, Wolf C. Decision 
making in abdominoplasty. Aesthetic Plast Surg. 2007;31(2):117-27.

20. Staalesen T, Elander A, Strandell A, Bergh C. A systematic review of outcomes of abdominoplasty. J Plast Surg Hand Surg. 2012;46(3-4):139-44.

21. Ardehali B, Fiorentino F. A meta-analysis of the effects of abdominoplasty modifications on the incidence of postoperative seroma. Aesthet Surg J. 2017;37(10):1136-43.

22. Abhyankar SV, Rajguru AG, Patil PA. Anatomical localization of the umbilicus: an Indian study. Plast Reconstr Surg. 2006;117(4):1153-7.
Received in: 01/10/2017

Accepted for publication: 01/03/2018

Conflict of interest: none.

Source of funding: none.

\section{Mailing address:}

Júlio Wilson Fernandes

E-mail: cirurgiaplasticajwf@uol.com.br / renatadamin@hotmail.com

(cc) BY 